\title{
THE IMPLEMENTATION OF STANDARD EDUCATION PROCESS IN ISLAMIC EDUCATION AND CHARACTER AT SMA NEGERI 17 MAKASSAR
}

\author{
Muh. Asrar ${ }^{1}$ \\ Muh. Khalifah Mustami ${ }^{2}$ \\ Muzakkir ${ }^{3}$ \\ Ulfiani Rahman ${ }^{4}$ \\ Postgraduate Program of UIN Alauddin Makassar ${ }^{1,2,3,4}$
}

\begin{abstract}
This study aims to describe and analyze the process of implementing standard educational processes in Islamic religious education and Characters subjects (PAI and Budi Pekerti) at SMA Negeri 17 Makassar, the supporting and inhibiting factors for implementing educational process standards, and the success rate of implementing Standard Education Process in supporting the success of Islamic Education and Character at SMA Negeri 17 Makassar. Qualitative research is included in this study. The method employed is Pedagogical. Teachers of Islamic religious education, school principals, education unit supervisors, and associated papers were used as data sources. Data was collected using the methods of observation, interviews, and documentation. Data analysis was carried out in three stages: data reduction, data presentation, and drawing conclusions. Testing the validity of the data is done by increasing persistence, doing triangulation, discussing with colleagues, and member checking. An important finding in this study is that the process of implementing the standard educational process on subjects of Islamic religious education and manners at SMA Negeri 17 Makassar begins with the preparation of a lesson plan. It refers to the Standard Education Process in terms of types, procedures, principles, and components in the lesson plan. After preparing the plan, the teacher carries out the learning process using a scientific approach and learning models that are relevant to the Standard Education Process. Furthermore, the teacher analyses the learning process and results both during and after the learning process takes place using authentic assessments and other forms of assessment appropriate to the domains of attitudes, knowledge, and skills.
\end{abstract}

Keywords: Standard Education Process; Islamic Education

\section{BACKGROUND}

The implementation of Islamic religious education and character in public schools is still receiving sharp attention because of its inability to overcome various important issues in people's lives. It has not been able to become the spirit or spirit that encourages the growth of harmony in everyday life. ${ }^{1}$

So far, Islamic religious education and character have failed to lead students to become human beings who believe and fear God Almighty and have noble character. However, it is recognized that in terms of achieving the knowledge aspect, it is quite

'Khuzaimah, Paradigma Pengembangan Kurikulum Penddidikan Agama Islam di Sekolah", Jurnal Kependidikan, V, no. 1 (2017): p. 82 
good. Still, it is considered that there is no significant correlation between the participants' religious knowledge. Educate with the characters they show in everyday life. There are still rampant deviant behaviour among students, such as promiscuity, fights between students, students involved in drugs and alcohol, students involved in violence such as robbers are often used as evidence of the failure of Islamic religious education and character in schools. ${ }^{2}$

The failure of Islamic religious education and character as described above cannot be separated from the weaknesses in schools' implementation of Islamic religious education and character education. Implementing Islamic religious education learning in schools is considered to touch more on the cognitive aspects and still rarely touches the affective and psychomotor aspects. As a result, students understand more about religious teachings theoretically and do not reach the level of practising them. As stated by Amin Abdullah that religious education is more concentrated on cognitive religious theoretical issues and is less concerned with the issue of how to change cognitive religious knowledge into meanings and values that need to be internalized in students through various means, media, and forums. ${ }^{3}$

Another weakness of implementing Islamic religious education and character education in schools is related to the use of learning models and methods. The learning of Islamic religious education and character has paid less attention to the method of delivery in the classroom, even if using certain methods, it tends to be very classic methods to continue to be practised and maintained in the present. While on the other hand, students need effective and practical learning methods to understand the subject matter quickly, precisely, and easily. ${ }^{4}$

It is still rare to consistently evaluate aspects of attitudes and skills after Graduation. The implementation of the assessment of Islamic religious education and character has been considered to pay more attention to the cognitive aspect by using a written test as an evaluation tool. Likewise, in determining grades, sometimes teachers or school principals pay more attention to the value of knowledge and skills than the value of students' attitudes.

The government has taken many steps to remedy the weaknesses in the implementation of religious education and character in schools, including placing moral education as the essential position, as evidenced by the national education goals, which state that:

"Pendidikan nasional berfungsi mengembangkan kemampuan dan membentuk watak serta peradaban bangsa yang bermartabat dalam rangka mencerdaskan kehidupan bangsa, bertujuan untuk berkembangnya potensi peserta didik agar menjadi manusia yang beriman dan bertakwa kepada Tuhan Yang Maha Esa, berakhlak mulia, sehat, berilmu, cakap, kreatif, mandiri, dan menjadi warga negara yang demokratis serta bertanggung jawab. ${ }^{\prime 5}$

\footnotetext{
${ }^{2}$ Muhaimin, Paradigma Pendidikan Islam; Upaya Mengefektifkan Pendidikan Agama Islam di Sekolah, (Bandung: Remaja Rosdakarya, 2001) pp. 89-90

${ }^{3}$ Amin Abdullah, Problem Epistemologis-Metodologis Pendidikan Islam, dalam Abd. Munir Mulkhan, et-al, Religisitas Iptek (Yogyakarta: Pustaka Pelajar, 1998), pp. 49-65

${ }^{4}$ Mumtazul Fikri, Konsep Pendidikan Islam Pendekatan Metode Pengajaran", Islam Futura XI, no.1 (2011): p. 117

${ }^{5}$ Republik Indonesia, Undang-undang R.I. Nomor 20 Tahun 2003 Tentang Sistem Pendidikan Nasional, chapter I article 3.
} 
National education aims to further elaborate on Islamic religious education and character education in high school (SMA). Islamic religious education and character education attempts to promote faith in students by providing and developing their knowledge, appreciation, practice, habituation, and experience of Islam. The goal is to become a Muslim who continues to develop his faith and piety to Allah SWT. to become Indonesian people who are religiously obedient and have noble character. Can be human beings who are knowledgeable, diligent in worship, intelligent, productive, honest, fair, ethical, disciplined, tolerant (tasamuh), maintain personal and social harmony and develop a religious culture in the school community. ${ }^{6}$

The emphasis of religious education in high school is to increase spiritual potential and shape students to become human beings who believe and fear God Almighty and have a noble character, including ethics, character, and morals as the embodiment of religious education. Increasing spiritual potential includes understanding and inculcating religious values and practising these values in individual and collective life. The increase in spiritual potential ultimately aims at optimizing various potentials possessed by humans whose actualization reflects their dignity as God's creatures.

Realizing the goals of education as stated above, the government, in this case, represented by schools, must be able to guarantee the implementation of quality education. Quality education must start from a quality learning process. And a quality learning process must be supported by quality teachers too.

Teachers are the foundation of a good education. The ability to develop a lesson in line with the subject matter and students' characteristics distinguishes quality teachers. Teachers of high quality are also known for their ability to carry out the learning process in the most effective manner and with the most appropriate learning medium, resulting in improved learning results. Furthermore, the capacity to analyze appropriate learning processes and outcomes distinguishes outstanding teachers. Teachers play a critical role in ensuring high-quality learning, but talented teachers aren't enough; quality principals and supervisors are as crucial. Principals and supervisors are in charge of assisting, supervising, and evaluating instructors as they prepare lesson plans, implement learning, and evaluate learning processes and outcomes.

Learning must be managed professionally. All elements involved in it must have adequate knowledge, skills and experience. Besides that, they must also have a strong commitment and spirit of service. Teachers of Islamic religious education and manners should not view their duties as mere professional duties. Still, more than that, they must view them as the duties of the Almighty Creator, Allah SWT. which will be assessed and accounted for in the future. As Allah SWT said in QS. surah at-Taubah/9:105. as follows:

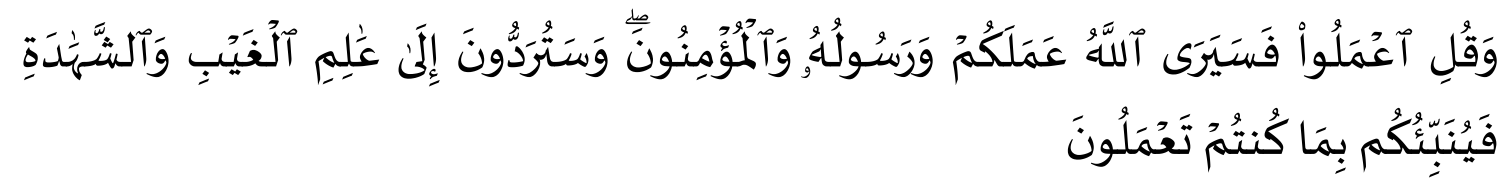

Translation:

" And say (O Muhammad SAW) "Do deeds! Allah will see your deeds, and (so will) His Messenger and the believers. And you will be brought back to the All-

${ }^{6}$ Departemen Pendidikan Nasional, Kurikulum Pendidikan Agama Islam SMA/MA Tahun 2006 (Jakarta: Depdikbud RI, 2006), p. 2. 
Knower of the unseen and the seen. Then He will inform you of what you used to do."

This verse aims to encourage people to introspect and monitor their deeds by reminding them that every good deed and bad deed has a nat ure that cannot be hidden and has witnesses who know and see its essence, namely the Messenger of Allah. And the witnesses of the deeds of the believers after Allah SWT. Then Allah will remove the veil that covers the eyes of those who do these deeds on the Day of Resurrection so that they too will know and see the nature of their deeds. ${ }^{7}$

From an educational perspective, this verse can be interpreted that Allah SWT ordered all believers, including teachers, school principals and supervisors of educational units, to work professionally and sincerely because every work done will be judged by Allah and His Messengers and believers and will be accounted for before Allah.

In order for the quality of learning to be guaranteed, the performance of teachers, school principals and supervisors of education units can be measured, the government through the regulation of the Minister of National Education Number 41 of 2007 as amended several times and most recently with the regulation of the Minister of Education and Culture Number 22 of 2016 concerning Basic Education Process Standards and Secondary, setting a standard known as the standard of the education process. The standard of the educational process is the national standard of education relating to the implementation of learning in primary and secondary education units throughout the jurisdiction of the Unitary State of the Republic of Indonesia. The Standard Education Process contains how to plan the learning process, implement the learning process, assess learning outcomes, and supervise the learning process to implement an effective and efficient learning process.

Teachers must use the educational process standard as a guide in carrying out the complete series of learning processes in order to ensure effective and efficient implementation of the learning process and achievement of learning outcomes. The principal must use the educational process standard as a guide in developing various school policies to promote the educational process's performance and a barometer to monitor the education program's success in the school he leads. Meanwhile, the education unit's supervisor must use the educational process's standard to provide direction to school principals and instructors on managing the learning process in their target schools.

SMA Negeri 17 Makassar is a secondary level education unit that carries out Islamic religious education and character education as mandatory subjects for Muslim students. The question then is whether the teachers of Islamic religious education and manners at SMA Negeri 17 Makassar have implemented the standard of the education process in the subjects of Islamic religious education and character? And can the implementation of the standard of the educational process support the success of Islamic religious education and character in schools?

Based on the preliminary research results, the authors found that teachers of Islamic religious education and character at SMA Negeri 17 Makassar have made the standard of the educational process as a guide in learning Islamic education and character. It starts with planning and implementing learning and assessing learning processes and outcomes. However, there are still weaknesses and shortcomings in the

${ }^{7}$ M. Quraish Shihab, Tafsir Al-Mishbah, (Jakarta; Lentera Hati, 2002) p. 712 
implementation process that need improvement, both related to learning planning, learning implementation, learning assessment, and monitoring the learning process. To obtain scientific and in-depth answers, the authors feel the need to examine how SMA Negeri 17 Makassar implements the standard of the educational process in Islamic religious education subjects and character. Whether there are supporting and inhibiting factors in the implementation process and how the success rate of implementation of the educational process standards supports the success of Islamic religious education and character in schools.

\section{THEORETICAL FRAMEWORK}

\section{A. Definition and Functions of The Standards Educational Process}

\section{Definition of The Standards Educational Process}

Three important things need to be underlined: First, the standard of the educational process is a national standard that applies to every formal education institution at a certain level of education wherever the educational institution is national. Thus, all schools should carry out the learning process as formulated in the standard of the educational process. Second, the standard of the educational process is related to the implementation of learning. It becomes a guideline for every formal education institution at a certain level of education in carrying out the learning process. Third, the standard of the educational process contains criteria regarding the implementation of learning in educational units to achieve graduate competency standards. Therefore, the learning process must be directed to achieve graduate competency standards.

Thus, the standard of the education process is a national guideline for implementing the learning process in primary and secondary education units throughout the jurisdiction of the Unitary State of the Republic of Indonesia to achieve graduate competence. The standard of the educational process includes planning the learning process, implementing the learning process, evaluating the learning process and outcomes, and supervising the learning process for the effective and efficient implementation of the learning process.

\section{The function of the Standards Educational Process}

As a guide in the implementation of the learning process, the standard of the educational process has several functions related to all components involved with the learning process in the education unit, especially teachers, school principals, and education unit supervisors.

\section{a) Functions of the Standards of the Education Process for Teachers;}

The teacher is a very decisive element in implementing the educational process in schools. The success or failure of education is largely determined by the teacher's quality of the learning process. Concerning the learning process, there are at least three roles that must be carried out by teachers, namely as planners, implementers and assessors of learning processes and outcomes. The teacher must have a reference or guideline to carry out these three roles. One of the guidelines in question is the standard of the educational process. Thus, the standard function of the education process for teachers is to carry out all activities related to learning, from planning, implementation 
to the assessment of learning processes and outcomes. Therefore, teachers must clearly understand the standard of the educational process.

b) Functions of the Standards of the Educational Process on the Principal;

The success of the learning process in schools institutionally is the principal's responsibility. Every principal must be able to play himself as an education manager. The principal has the duty and obligation to direct all educational activities in the school he leads, especially the learning process activities in order to ensure the achievement of educational goals. To carry out these duties and obligations, the principal must also clearly understand the standard principles of the educational process. According to Sanjaya, there are at least two standard functions of the education process for school principals: First, as the main guide in formulating various school policies, especially in determining and seeking the availability of various facilities and infrastructure needed to support the success of the educational process. Second, as a barometer or tool to measure the education program's success in the school, he leads. ${ }^{8}$

c) The function of Educational Process Standards on Education Unit Supervisors;

Education unit supervisor is a person who is given the responsibility to carry out supervision of the implementation of education in schools in accordance with their assignments and improve the quality of the teaching and learning process/guidance and learning achievement results/guidance of students in order to achieve educational goals. The main task of the education unit supervisor is to carry out academic and managerial supervisory duties in the education unit. It includes the preparation of supervision programs, implementation of guidance, monitoring of the implementation of national education standards, assessment, professional guidance and training of educators, evaluation of the results of the implementation of supervision programs, and implementation of supervisory duties in the particular regions. In carrying out their duties, educational unit supervisors, especially the task of improving the quality of the learning process, must also pay attention to the standard principles of the educational process. The function of the education process's standard for the education unit's supervisor is as a guide, benchmark or measure in determining which parts need to be perfected or improved by principals and teachers in managing the learning process.

\section{B. Prerequisites for the Implementation of the Learning Process}

Prerequisites for implementing the learning process are conditions that must be met before carrying out the learning process. Prerequisites for implementing learning as regulated in the standard of the educational process include face-to-face time allocation, study groups, textbooks, and class management. ${ }^{9}$

The time allocation for face-to-face learning for SMA is 45 minutes for one lesson hour. The number of students for each study group is 36 people, while the number of textbooks is adjusted to the needs of students or with a ratio of one student to one book for each subject.

\footnotetext{
${ }^{8}$ Wina Sanjaya,Strategi Pembelajaran Berorientasi Standar Proses Pendidikan, (Jakarta: Kencana, 2009), p. 6

${ }^{9}$ Standar Proses Pendidikan Nomor 22 Tahun 2016, Bab IV, p. 9.
} 
Class management is the skill of educators to create and maintain optimal learning conditions and control them if there are disturbances in the teaching and learning process. ${ }^{10}$

Teachers must be able to create conducive classroom conditions so as to enable effective and efficient teaching and learning processes. The teacher's main task is to create an atmosphere in the classroom so that teaching and learning interactions occur that can motivate students to study well and seriously.

The ability of the instructor to manage the class, both physically and nonphysically, has a significant impact on the creation of conducive classroom settings. Physical class management is related to class arrangement and student seating arrangements, while non-physical management is related to the appearance and attitude of the teacher in delivering subject matter.

Seating arrangements for students in the class can be made individually and in groups. Individual placement is based on the assumption that students have different backgrounds in terms of intelligence, talent, inclination, motivation, etc. ${ }^{11}$

The individual differences of these students provide insight to the teacher that learning strategies must pay attention to these individual differences. In other words, educators must use an individual approach in their teaching strategies so that students are expected to have an optimal level of mastery of the material.

The placement of students in groups holds the view that every student has differences and similarities. The differences between one student and another are not to be contradicted or separated but must be integrated. Intelligent students, for example, must be able to be united with less intelligent students so that intelligent students can help less intelligent students.

In addition, the group approach also assumes that every student tends to make friends and groups to gain life experience and socialize in meeting their life needs. So that social solidarity is built in the class.

In addition to skills in managing classes, educators must also have attitudes and skills in delivering subject matter in front of the class. In the national education standard, it is explained that the skills that educators must have in managing the classroom are:

1. The volume and intonation of the teacher's voice in the learning process must be heard well by students.

2. The teacher's speech is polite and can be understood by students;

3. The teacher adjusts the subject matter to the speed and learning ability of students;

4. The teacher creates order, discipline, comfort, safety and compliance with regulations in carrying out the learning process;

5. The teacher provides reinforcement and feedback on the responses and learning outcomes of students during the learning process;

6. Teachers respect students regardless of background, religion, ethnicity, gender, and socioeconomic status;

7. The teacher respects the opinions of students;

8. The teacher wears polite, clean and tidy clothes;

\footnotetext{
${ }^{10}$ Rusman, Model-model Pembelajaran, Mengembangkan Profesionalisme Guru, p. 90.

${ }^{11}$ Abuddin Nata, Perspektif Islam Tentang Strategi Pembelajaran(Cet. II; Kencana, 2011), p. 152.
} 
9. At the beginning of each semester, the teacher conveys the syllabus of the subjects he teaches;

10. The teacher starts and ends the learning process according to the scheduled time.

Abuddin Nata also stated that to manage the class well, the teacher must implement several principles: First, the principle of warmth and enthusiasm. Teachers who are warm and familiar with students will always show enthusiasm for their duties or activities. It will support success in carrying out classroom management. Second, creating various challenges that allow an educator to be passionate and continue to learn in overcoming various things. It can reduce the possibility of deviant behaviour. Third, using models, approaches, techniques, styles, media, and various teaching tools can increase enthusiasm for learning and eliminate boredom. Fourth, the use of methods and actions that are more flexible, flexible, and fun. This situation is expected to eliminate various disturbances that may occur in the classroom. Fifth, seek positive things for students and avoid as far as possible mistakes that can provoke students to have a negative attitude towards educators. Sixth, promoting an exemplary attitude in front of students can further encourage them to become people who are always obedient to educators, not because of fear but because of pride and admiration. ${ }^{12}$

Meanwhile, according to Rusman, the things that teachers must do in order to create and maintain optimal learning conditions are to show a responsive attitude, pay attention, focus attention, provide clear instructions, reprimand if students do deviant actions and provide reinforcement. ${ }^{13}$

Thus, classroom management is actually part of an important task that teachers must carry out. Every time a teacher enters a class, they actually face two interrelated problems. First, the problems are related to success in leading the learning process and delivering students to predetermined learning goals. The success of teachers in leading learning is related to their mastery of the material they teach and their skills in conveying them to students. Second, problems related to the creation of classroom conditions that support teaching and learning activities in an orderly manner. The better and more pleasant the classroom conditions, the greater the chance to achieve success in the learning process.

\section{Learning Activities}

Learning activities are processes of interaction between students, between students and teachers and learning resources in a learning environment to achieve goals. As stipulated in the standard educational process, learning activities are divided into three stages: preliminary activities, core activities, and closing activities.

\section{Preliminary Activity}

Preliminary activities are a series of activities carried out by teachers to prepare students for learning activities. Preliminary activities are basically activities that must be carried out by teachers and students every time the implementation of a lesson. The function of preliminary activities is mainly to create an effective initial learning atmosphere that allows students to follow the learning process well. In the standard

\footnotetext{
${ }^{12}$ Abuddin Nata, Perspektif Islam Tentang Strategi Pembelajaran, p. 350.

${ }^{13}$ Rusman, Model-model Pembelajaran, Mengembangkan Profesionalisme Guru, p. 90.
} 
process, it is explained that in the preliminary activities, the teacher must do the following things:

a) Prepare students psychologically and physically to participate in the learning process;

b) Provide students with contextual learning motivation according to the benefits and application of teaching materials in everyday life by providing examples with local, national and international comparisons, and adapted to the characteristics and levels of students;

c) Asking questions that relate previous knowledge to the material to be studied;

d) Describe the learning objectives or basic competencies to be achieved;

e) Delivering material coverage and explanation/description of activities according to the syllabus. ${ }^{14}$

User Usman suggests that the activities that must be carried out by the teacher in the introductory activity or in opening learning activities are as follows: First, attract the attention of students with teaching styles, use of learning media, and varied patterns of learning interactions; Second, generate motivation, accompanied by warmth and enthusiasm, arouse curiosity, express conflicting ideas, and pay attention to the interests or interests of students; Third, providing references through various efforts, such as stating learning objectives and task limits, suggesting steps to be taken, reminding the main issues to be discussed, and asking several questions; Fourth, providing apperception, namely providing a link between the previous material and the material to be studied so that the material studied is a unified whole that is not separated. ${ }^{15}$

Thus, the teacher should not ignore when opening the lesson are preparing students physically and psychologically to learn, doing apperception, motivating students to learn, and explaining the objectives or basic competencies to be achieved.

An explanation of the objectives and basic competencies to be achieved in the initial activity is very important for the teacher. Clear goals can make students understand where they want to be taken. Understanding students about learning objectives can foster students' interest in learning, which can increase their motivation. The clearer the goals to be achieved, the stronger the motivation of students to learn.

In the learning system, the goal is the main component. All activities of teachers and students must be focused on efforts to achieve the goals that have been determined. The success of a learning process is measured by students' success in achieving learning objectives. In addition, learning objectives can also determine a strategy that the teacher must use.

There are several reasons why objectives need to be explained in learning activities. First, clear objectives can be used to evaluate the effectiveness of the success of the learning process. A learning process is said to be successful when students achieve their goals optimally. Second, learning objectives can be used as guidelines and learning guides for students. Clear objectives can guide students in carrying out learning activities. Third, learning objectives can assist in designing learning systems, determining learning models or strategies, tools, media, and evaluation tools to see

\footnotetext{
${ }^{14}$ Standar Proses Pendidikan Nomor 22 Tahun 2016, Bab. IV, p. 11.

${ }^{15}$ Uzer Usman, Menjadi Guru Profesional, (Bandung: Remaja Rosdakarya, 1992), p. 85.
} 
student learning success. Fourth, learning objectives can be used as controls in determining the limits and quality of learning. ${ }^{16}$

All activities summarized in the preliminary activities are activities to open learning. Opening learning is the initial conditioning. The mental and attention of students are focused on the material to be taught and have high motivation to continue to follow the learning until it is finished with a high spirit of concentration.

Opening learning activities must be carried out as well as possible because it will affect the course of subsequent learning activities with a good start. If the opening activities are successful, the core and closing activities may be successful.

\section{Core activities}

Core activities are activities to achieve basic competencies. The core activity provides students with experience in exploring and interacting with learning resources. The core activities in learning include the use of strategies, models or learning methods, the use of learning media, the use of learning resources, and all activities carried out by both teachers and students to achieve learning objectives.

Learning activities as described in Government Regulation Number 19 of 2005 concerning National Education Standards as amended by Government Regulation Number 32 of 2013 that learning activities must be carried out interactively, inspiring, fun, challenging, motivating students to participate actively, and providing sufficient space for the initiative, creativity, and independence in accordance with the talents, interests, and physical and psychological development of students. ${ }^{17}$

Interactive learning activities allow the interaction process between teachers and students, between students and students, and between students and their environment so that students' abilities will develop both mentally and intellectually.

Inspirational learning activities are activities that allow students to try and do something. Teachers must provide opportunities for students to act and think according to their own inspiration because knowledge is basically subjective which can be interpreted by each subject of study.

Fun learning activities are activities that make students free from fear and tension. The class must be organized properly and tastefully in order to provide an enjoyable learning environment. Challenging learning activities can develop students' thinking skills by stimulating their brain work to the maximum. Educators must cultivate and develop students' curiosity through trial-and-error activities, intuitive thinking or exploration.

Motivating learning activities are activities that encourage students to act and do something based on their own will. Learning for students is a necessity so that learning is not just to get grades or praise but is driven by a desire to fulfil their needs.

\section{Closing Activities}

Closing activities are activities carried out to end learning activities. In the standard of the educational process, it is explained that what the teacher does in the final activity are: first, together with the students or alone make learning conclusions; second, conduct an assessment and or reflection on the activities that have been carried out consistently and programmed; third, providing feedback on the learning process and

\footnotetext{
${ }^{16}$ Wina Sanjaya, Strategi Pembelajaran Berorientasi Standar Proses Pendidikan, p. 64.

${ }^{17}$ Peraturan Pemerintah No. 32 Tahun 2013 tentang Standar Nasional Pendidikan
} 
results; fourth, planning follow-up activities in the form of remedial learning, enrichment, guidance services, giving assignments to both individuals and groups; fifth, submit the lesson plan at the next meeting. ${ }^{18}$

Meanwhile, according to Wina Sanjaya, ending learning can be done by: First, summarizing or outlining the issues that have just been discussed. So students get a comprehensive and clear picture of the main issues; Second, consolidating the attention of students on the main things so that the information that has been received can arouse interest in learning more. Third, organize the activities that have been carried out to form a new understanding of the material that has been studied; Fourth, provide followup and suggestions to broaden insight related to the subject matter that has been discussed. ${ }^{19}$

Thus, teachers are required to start learning well and have to close the lesson well.

\section{Supporting and Inhibiting Factors in the Implementation of Educational Process Standards}

Several factors can affect the implementation of the standard of the educational process. These factors can be analyzed from the components related to the implementation of learning activities in schools, namely teacher factors, student factors, available facilities and infrastructure factors, as well as coaching and supervision factors from school principals and education unit supervisors.

\section{Teacher Factor}

The teacher in the learning process plays a very important role. The teacher is a very dominant determining factor in education in general because the teacher is the core of the overall educational process. In the learning process, the teacher acts as a model or role model for the students he teaches and acts as a manager of the learning process. As a learning manager, there are several tasks that the teacher must be able to do to ensure the effective implementation of the learning process, namely:

a) Teachers must be able to arrange lesson plans

The success of the learning process is influenced by the lesson plans prepared by the teacher. Therefore, one of the abilities that a teacher must possess is designing interesting learning according to field conditions and needs.

Teachers must strive to organize and organize so that the planned learning can make students need to learn, want to learn, be motivated to learn, facilitate learning, and be interested in continuous learning. ${ }^{20}$

The core of lesson planning activities is determining the learning objectives, selecting materials, selecting and establishing suitable learning strategies, determining appropriate media, as well as compiling and determining forms and assessment instruments. Those items will be used to measure the achievement of learning objectives that are known as compiling a syllabus and the lesson plan in the educational process.

\footnotetext{
${ }^{18}$ Rusman,Model-model Pembelajaran, Mengembangkan Profesionalisme Guru, p. 92-93.

${ }^{19}$ Wina Sanjaya, Strategi Pembelajaran Berorientasi Standar Proses Pendidikan, p. 43-44.

${ }^{20}$ Muhaimin, Paradigma Pendidikan Islam Upaya Mengefektifkan Pendidikan agama Islam dan budi pekerti di Sekolah (Bandung: Remaja Rosdakarya, 2012), p. 185.
} 
The more perfect the lesson plan will be, the more it will be possible for the learning to run effectively. On the contrary, the worse or even unplanned, the more the learning will be undirected and far from the desired results.

b) Teachers must be able to carry out the learning process

As implementers of the learning process, teachers must be able to create an interactive, inspiring, fun, challenging learning process, motivate students to participate actively, and provide sufficient space for the initiative, creativity, and independence according to their talents, interests, and learners physical and psychological development. ${ }^{21}$

To realize the learning process as stated above, the teacher must carry three main tasks, namely opening learning, managing learning, and closing learning activities. ${ }^{22}$

The first task that must be done by the teacher as an implementer of the learning process is to open learning. Opening learning is an effort made by the teacher to create preconditions for students so that their mental and attention are focused on what they are going to learn so that these efforts will positively affect learning activities.

The activity of opening learning is a very important activity for teachers because it will affect the course of subsequent learning activities with a good start. If successful in carrying out the opening activities, the core and closing activities may also be successful.

In the Process Standards for Primary and Secondary Education Units, it is explained that what teachers must do in preliminary activities is to prepare students psychologically and physically to take part in the learning process, perform apperception, which is to link previous knowledge with the material to be studied, explain the learning objectives or basic competencies to be studied will be achieved and convey the scope of the material and an explanation of the description of activities in accordance with the syllabus and lesson plans.

The second task that the teacher must carry out as the executor of the learning process is managing learning or in more popular terms managing the class.

Managing the classroom is an activity related to the teacher's ability to create and maintain optimal learning conditions and control them if there are disturbances in the teaching and learning process. ${ }^{23}$

Several things that educators must do to create and maintain optimal learning conditions. It includes arranging the facilities and infrastructure in the classroom, arranging students so that they are in an orderly, tidy state, and controlling them when they do things that have nothing to do with teaching and learning activities.

In addition to the efforts mentioned above, to maintain optimal teaching and learning conditions, teachers must master the material they teach, choose and use appropriate models, and use interesting learning media.

Thus, classroom management is an important task that the teacher must carry out at every learning activity. When carrying out the learning process in the classroom, the teacher faces two interrelated tasks. The first is a task related to success in leading

${ }^{21}$ Republik Indonesia, Peraturan Menteri Pendidikan Nasional Nomor 41 Tentang Standar Proses Untuk Satuan Pendidikan Dasar dan Menengah, dalam Kumpulan Permendiknas Tentang Standar Nasional Pendidikan dan Panduan KTSP (Jakarta: Departemen Pendidikan Nasional), p. 431.

${ }^{22}$ Rusman Model-model Pembelajaran, Mengembangkan Profesionalisme Guru, p. 71.

${ }^{23}$ Abuddin Nata, Perspektif Islam Tentang Strategi Pembelajaran, p. 339 
the learning process and delivering students to learning goals. This task is related to mastery of the subject matter he teaches and skills in conveying it to students. Both tasks are related to creating classroom conditions that support the orderly implementation of the learning process. This task is related to the teacher's ability to manage facilities and infrastructure in the classroom, regulate and control students.

The third task that must be done by the teacher as the executor of the learning process is to close the learning process. Closing learning activities is an activity carried out by the teacher to end learning activities. This activity is intended to provide a comprehensive picture of what students have learned and determine students' level of achievement and the level of success of teachers in the learning process.

To close the learning as described in the standard of the education process, the teacher and students, both individually and in groups, reflect on evaluating the entire series of learning activities and the results obtained and then jointly find direct and indirect benefits from the learning outcomes that have been carried out. Ongoing; provide feedback on the learning process and results; carry out follow-up activities in the form of assignments, both individual and group assignments; and inform the plan of learning activities for the next meeting.

c) Teachers must be able to assess learning processes and outcomes

The factor that is no less important in determining the success of the learning process is the assessment factor. Therefore, teachers must be able to be good judges. Assessment is carried out to determine whether the goals that have been formulated have been achieved or not. Whether the material taught has been mastered or not, and whether the models and media used are appropriate.

The teacher must master various forms of assessment and be able to make assessment plans in order to become a good evaluator. Developing assessment instruments, carrying out assessments, managing assessment results, making reports on assessment results and planning follow-up on assessment results are the things that should be mastered.

The description above shows that the teacher has a major and decisive role in the success of the teaching and learning process, where teaching and learning activities are the core of the overall educational process.

\section{III.RESEARCH METHODS}

This research includes qualitative research. The approach used is pedagogical. Data sources were obtained from Islamic religious education teachers, school principals, education unit supervisors and related documents. Data was collected using the methods of observation, interviews, and documentation. Data analysis was carried out in three stages: data reduction, data presentation, and drawing conclusions. Testing the validity of the data is done by increasing persistence, doing triangulation, discussing with colleagues, and member checking.

\section{RESEARCH RESULTS AND DISCUSSION}

A. Supporting and Inhibiting Factors in the Implementation of the Learning Process of Islamic Religious Education and Character at SMA Negeri 17 Makassar 
As previously explained, implementing the standard educational process in Islamic religious education and character education at SMA Negeri 17 Makassar has been carried out well in several aspects. However, there are still aspects that still need to be improved. Conditions like this certainly cannot be separated from the supporting and inhibiting factors.

Factors supporting and inhibiting the implementation of standardized educational processes in Islamic religious education subjects and character can be analyzed from all aspects directly related to the implementation of the learning process, including aspects of teachers, students, facilities and infrastructure, and supervisors of education units.

\section{Teacher Aspect}

The teacher is the main actor who plans, implements and assesses the learning process and outcomes. Therefore, the teacher is an element that determines the success of the learning process. However good the curriculum and complete facilities and infrastructure are without being balanced with the ability of teachers to implement them. The curriculum is less meaningful. Thus, a teacher in addition to having an educational background must also have various abilities related to his duties.

Factors supporting and inhibiting the implementation of standard educational processes in Islamic religious education subjects and manners at SMA Negeri 17 Makassar from the teacher aspect can be seen from the qualifications, background and abilities of Islamic religious education teachers.

The Qualifications and educational background of Islamic religious education and character teachers at SMA Negeri 17 Makassar are based on the data previously presented. It was obtained information that teachers of Islamic religious education who teach at SMA Negeri 17 Makassar on average have bachelor's or strata one qualifications and have an Islamic educational background.

Thus the qualifications and backgrounds of these Islamic religious education teachers are one of the supporting factors for the implementation of the standard educational process at SMA Negeri 17 Makassar as stated in the teacher and lecturer law that teacher qualifications must be obtained through a university degree program or four diploma program.

Meanwhile, the ability of teachers who support the implementation of standard educational processes in Islamic religious education and character at SMA Negeri 17 Makassar is to prepare the lesson plan. As previously explained, Islamic religious education teachers have prepared learning plans in the form of syllabus and lesson plans that have referred to the standard of the educational process. Teachers of Islamic religious education and character at SMA Negeri 17 Makassar have developed lesson plans that support the application of a scientific approach and authentic assessment in learning.

Another teacher's ability that also supports the implementation of the standard of the educational process is the ability to carry out the learning process and assess the learning process. As acknowledged by Jumriati, the deputy principal of the curriculum field, all teachers of Islamic religious education and character at SMA Negeri 17 Makassar have good abilities, especially in applying a scientific approach as well as in applying various forms of assessment. ${ }^{24}$

\footnotetext{
${ }^{24} \mathrm{R} 5$, Wakasek Kurikulum SMA Negeri 17 Makassar, wawancara oleh penulis di SMA Negeri
} 
The inhibiting factor for the implementation of the standard process from the teacher's perspective is the lack of teacher ability in using the learning models recommended in the standard educational process, such as problem-based learning models and project-based learning models, likewise, the ability of teachers to utilize learning media by the demands of the standard of the educational process.

The 2013 curriculum and educational process standards require teachers, including Islamic religious education teachers, to use learning models that are relevant to a scientific approach or scientific approach, including inquiry, discovery, problembased, project-based, cooperative learning and contextual learning models.

The ability of teachers to choose and use learning media also still needs to be improved. Islamic religious education teachers at SMA Negeri 17 Makassar are still limited in using learning media. The learning media that they often use are still simple, while media such as films or videos and online media such as the internet are highly recommended in the curriculum and standards of the education process.

The use of media in the form of films and videos in learning provides many benefits, including describing an event or the process of something happening, which can create the impression of space and time. So it is very suitable to use in learning activities, including Islamic religious education and character. For example, teaching about the corpse procession, pilgrimage, Umrah, and the material for Islamic dates, the teacher can use films or videos as media.

The use of internet media or online media in learning provides many advantages, including making it easy for students to access information related to subject matter widely and quickly compared to looking for information through books. Making it easier for students to find answers or solutions to the problems they face in learning also allows students to discuss and exchange ideas with peers easily and quickly.

Thus the factors that need to get attention from various parties are increasing the ability of Islamic religious education teachers, especially the ability to apply various models and strategies in learning, the ability to use learning media, especially film, video and internet media.

\section{Student Aspect}

Learners are those whose parents specifically submit to take part in learning held at schools, aiming to become human beings who are knowledgeable, skilled, experienced, have personality, have noble character, and are independent.

As one of the components in learning activities, students have a huge influence on the success of the learning process. The success of the learning process is influenced by the number of students in the class, students' motivation in learning, basic abilities and backgrounds possessed by students.

The factors that support the implementation of the standard educational process in Islamic religious education subjects at SMA Negeri 17 Makassar from the aspect of students are the number of students in one study group is not too many as previously explained that the average number of students in one class is 36 some people even less than that. This amount is in accordance with the demands of the standard of the educational process, namely that the number of students in a study group for the high school level is a maximum of 36 people.

17 Makassar, 13 Juli 2020 
The number of students who are not too many in one class makes it easier for teachers to control the class, provide guidance and supervision, and make it easier for teachers to monitor the progress of student learning outcomes. While on the student side, this limitation provides many opportunities for each student to ask the teacher about subject matter that he has not understood.

While the inhibiting factors for the implementation of the standard educational process from the aspect of students can be seen from the data from the author's interviews with several related parties:

R2, stated that: One of the factors that influence the learning process of Islamic religious education and character is the motivation of students in learning. According to him, there are still students who are less interested in studying Islamic religious education subjects and manners because they consider Islamic religious education to be a subject that is not tested nationally. ${ }^{25}$

R3, also stated that: Another aspect that is still an obstacle in learning Islamic religious education is the weak ability of students to read the holy book al-Qur'an. ${ }^{26}$

R4 also stated the same thing: There are still many students who are not fluent in reading the Qur'an. There are even students who have not been able to pronounce the hijaiyah letters correctly. ${ }^{27}$

Based on the description above, there are two factors that are still an obstacle to the implementation of process standards in the subjects of Islamic religious education and character at SMA Negeri 17 Makassar from the aspect of students, namely: the motivation of some students in learning is still low, and the ability of some students in reading the verses of the Qur'an is also still low.

It is undeniable that motivation is one of the factors that greatly influence the learning process and learning outcomes. Students who have high learning motivation will devote all their abilities to learning so as to produce optimal learning outcomes. The higher the learning motivation of students, the higher the level of success that will be achieved. On the contrary, the lower the learning motivation of students, the lower the success that will be achieved. Likewise, the ability factor of the students. Students with high abilities usually tend to be serious in learning, and students with low abilities tend to be less serious in learning. It is undeniable that students have different abilities. Some have high, medium, and low abilities. These different abilities demand different treatment from educators.

\section{Aspects of Educational Facilities and Infrastructure}

Educational facilities are equipment and supplies that are directly used and support the educational process, especially the teaching and learning process, such as buildings, classrooms, tables and chairs, books, and learning tools and media. ${ }^{28}$

\footnotetext{
${ }^{25}$ R2, Guru Pendidikan Agama Islam SMA Negeri 17 Makassar, interviewed by author at SMA Negeri 17 Makassar, 7 Juli 2020

${ }^{26} \mathrm{R} 3$, Guru Pendidikan Agama Islam SMA Negeri 17 Makassar, interviewed by author at SMA Negeri 17 Makassar, 7 Juli 2020

${ }^{27}$ R4, Guru Pendidikan Agama Islam SMA Negeri 17 Makassar, interviewed by author at SMA Negeri 17 Makassar, 7 Juli 2020

${ }^{28}$ E.Mulyasa, Manajemen Berbasis Sekolah, (Bandung: PT. Remaja Rosdakarya, 2004), Cet. VII, p.49
} 
Educational infrastructure is all basic equipment that indirectly supports implementing the educational process in schools. ${ }^{29}$

Facilities and infrastructure are components that greatly influence the success of the learning process. The more complete the facilities and infrastructure, the more likely the learning process will be successful, and vice versa.

The factors that support the implementation of the standard educational process in religious and character education subjects at SMA Negeri 17 Makassar from the aspect of facilities are the availability of sufficient Islamic religious education textbooks, as previously stated that in learning Islamic religious education, students using textbooks that the school has prepared through the boss's funds with a ratio of one child to one book.

The availability of sufficient textbooks allows students to learn independently and individually so as to accelerate the pace of learning. They are helping teachers to use time effectively and reducing the burden on teachers in presenting subject matter so that more time for teachers to foster and develop student understanding, assisting teachers in presenting subject matter logically and systematically.

The inhibiting factors for the implementation of the standard of the educational process in the subjects of religious education and character at SMA Negeri 17 Makassar from the aspect of facilities and infrastructure can be seen from the results of the author's interview as follows:

According to R2, one of the obstacles faced by Islamic religious education teachers in relation to facilities is the lack of learning media in the form of laptops and LCD projectors prepared by schools so that teachers have to take turns using these facilities. ${ }^{30}$

$\mathrm{R} 3$, added that not all classes are equipped with LCD projectors, so if teachers and students want to use them, they have to move from one class to another. ${ }^{31}$ Another obstacle that is also still faced by Islamic religious education teachers, according to R4, is the lack of books to support learning Islamic religious education, the holy book of the Qur'an and the book of hadith. ${ }^{32}$

Thus, the inhibiting factor in implementing the standard educational process from the aspect of facilities is the lack of learning media prepared by schools, such as electronic media in the form of LCD projectors, computers or laptops. The factor that is also an obstacle to the lack of books to support the learning process of Islamic religious education subjects such as the holy book of the Qur'an and the book of hadith.

Therefore, the thing that must be a concern for the principal and all parties related to the learning process of Islamic religious education and character at SMA Negeri 17 Makassar is to complete learning facilities and infrastructure, especially with regard to the availability of learning media and learning support books.

There are two advantages for schools that have complete facilities and infrastructure. First, the completeness of facilities and infrastructure can foster the

\footnotetext{
${ }^{29}$ Ibrahim Bafadal, Seri Manajemen Peningkatan Mutu Pendidikan Berbasis Sekolah, Manajemen Perlengkapan Sekolah Teori dan Aplikasi (Jakarta: PT. Bumi Aksara, 2003),Cet. I, p.3

${ }^{30} \mathrm{R} 2$, Guru Pendidikan Agama Islam SMA Negeri 17 Makassar, interviewed by author at SMA Negeri 17 Makassar, 7 Juli 2020

${ }^{31} \mathrm{R} 3$, Guru Pendidikan Agama Islam SMA Negeri 17 Makassar, interviewed by author at SMA Negeri 17 Makassar, 7 Juli 2020

${ }^{32} \mathrm{R} 4$, Guru Pendidikan Agama Islam SMA Negeri 17 Makassar, interviewed by author at SMA Negeri 17 Makassar, 7 Juli 2020
} 
passion and motivation of teachers to teach. Teaching can be seen from two dimensions, namely, as a process of delivering subject matter and setting an environment that can stimulate students to learn. If teaching is seen as a process of delivering material, then learning facilities are needed in the form of tools and materials that can convey messages effectively and efficiently; Meanwhile, when teaching is seen as a process of regulating the environment so that students can learn, then facilities related to various learning resources are needed that can encourage students to learn. Thus, the availability of complete facilities allows teachers to have various options that can be used to carry out their teaching functions. Second, the completeness of facilities and infrastructure can provide various options for students to learn. Every student basically has a different learning style. Auditory type learners will easily learn through hearing, while students who are visual will find it easier to learn through sight. Learning outcomes will be maximized if students use their senses of sight and hearing.

\section{Supervision Aspect}

Supervision is one aspect that is very influential on the success of the learning process. Supervision of the learning process serves to control whether the learning process activities carried out by the teacher are based on predetermined process standards or not. In addition, supervision is also intended to provide direction, guidance, and examples of teaching implementation to teachers so that teachers can improve and improve their performance, which has an impact on improving student learning outcomes.

The supporting factor for the implementation of the standard of the education process from the aspect of supervision is the existence of guidance from school principals and supervisors of education units, although the supervision requirements and forms of guidance are felt to be lacking. Therefore, this deficiency is at the same time an inhibiting factor in the implementation of the standard of the educational process in the subjects of Islamic religious education and manners at SMA Negeri 17 Makassar.

As previously explained, the frequency of implementation of learning supervision, especially those carried out by Islamic religious education supervisors, is still lacking, namely once a semester on average or at most twice a year. Likewise, the form of supervision carried out is still focused on learning planning while the implementation of the learning process and assessment of learning in the classroom is still lacking attention, as well as the way of implementing supervision still revolves around examining learning devices, while observing the implementation of learning in class, discussing, giving examples, training, recording and consultation is still very minimal.

R7, a supervisor for Islamic education at the Makassar State Senior High School, said that the obstacles faced by supervisors were the lack of supervisors and the lack of supervisors' abilities. ${ }^{33}$

$\mathrm{R} 8$, the head of the Islamic religious education section at the Makassar city ministry of religion, also stated that the number of Islamic religious education supervisors was only 16 people, not proportional to the number of Islamic religious education teachers to be supervised. Besides that, the supervisor's ability is also not

${ }^{33}$ R7, Pengawas Pendidikan Agama Islam Kantor Kementerian Agama Kota Makassar interviewed by author at Kontor Kementerian Agama Kota Makassar, 9 Juli 2020 
adequate, so far according to him, the appointment of supervisors is still dominant, only fulfilling administrative requirements but not meeting competency requirements. ${ }^{34}$

In the Regulation of the Minister of State for Empowerment of State Apparatus and Bureaucratic Reform Number 21 of 2010 concerning Functional Positions of School Superintendents and their Credit Scores, it is explained that the workload of school supervisors is 37.5 hours per week including the implementation of coaching, monitoring, assessment, and mentoring in the target schools. Meanwhile, the target of supervision for each school supervisor for senior high schools/madrasah aliyah and vocational high schools is at least seven educational units and or 40 (forty) subject teachers/subject groups.

The main task of school supervisors is to carry out academic and managerial supervisory duties in educational units, which include the preparation of supervision programs, implementation of guidance, monitoring of the implementation of national education standards, assessment, mentoring and professional training of educators, evaluation of the results of the implementation of supervision programs, and implementation of supervisory duties in special areas. ${ }^{35}$

There needs to be a serious effort from the relevant parties to improve the quality of the implementation of supervision of Islamic religious education at the Makassar City Public Senior High School by increasing the number of supervisors for Islamic religious education. In addition, the existing supervisors need to increase the frequency of their attendance at schools and improve the quality of their guidance for Islamic religious education teachers and character in schools. So that through these efforts, the quality of the process and learning outcomes of Islamic religious education and character at SMA Negeri 17 Makassar in particular and SMA Negeri Makassar, in general, can be improved.

B. The Successful Implementation of Educational Process Standards in Supporting the Success of Islamic Religion and Character Education at SMA Negeri 17 Makassar

To determine the success rate of applying standard educational procedures in SMA Negeri 17 Makassar in supporting the success of Islamic religious education and character, it is necessary first to determine the level of success of Islamic religious education.

Islamic religious education is considered successful if it can meet the achievement indicators of predetermined competencies. Basically, three competencies can be used as a measure to determine the level of success of Islamic religious education and character at SMA Negeri 17 Makassar, namely the competence of attitudes, knowledge, and skills.

The achievement of student attitude competence can be seen from two things, namely spiritual attitudes and social attitudes. Spiritual attitude is measured by the extent to which students live and practice the teachings of Islam that they have learned. Social attitudes can be measured, among others, by the extent to which students can show honesty, discipline, responsibility, care, cooperation, tolerance, courtesy, and

\footnotetext{
${ }^{34} \mathrm{R} 8$, Kepala Seksi Pendidikan Agama Islam Kantor Kementerian Agama Kota Makassar interviewed by author at Kontor Kementerian Agama Kota Makassar, 9 Juli 2020.

${ }^{35}$ Peraturan Menteri Pendidikan dan Kebudayaan Nomor 143 Tahun 2014 tentang Petunjuk Teknis Pelaksanaan Jabatan Fungsional Pengawas Sekolah dan Angka Kreditnya.
} 
responsiveness in everyday life. The achievement of students' knowledge competencies can be measured from the extent to which students are able to know, understand, apply, analyze, and evaluate the subject matter that they have learned. Meanwhile, skill competencies can be measured from two aspects, namely abstract domain skills and concrete domains. Abstract domain skills are measured from the extent to which students are able to observe, ask questions, collect information, process information and present information. While the concrete realm can be measured from the ability of students to demonstrate or practise the skills they have learned.

To find out how the success rate of implementing process standards in increasing the success of Islamic religious education at SMA Negeri 17 Makassar can be seen from the results of the author's interviews with several parties as follows:

R2, stated that the implementation of standard educational processes using a scientific approach and various learning models as well as authentic assessments had a considerable influence on the success of Islamic religious education and character in SMA Negeri 17 Makassar. According to him, the application of various learning models oriented to the standard of the educational process enables students to discover and develop their own knowledge. At the same time, the authentic assessment provides strong motivation for students to master Islamic religious education material while practicing it in daily life, because to be able to pass in Islamic religious education subjects. Students' character must be able to integrate three competencies, namely the competence of attitudes, knowledge and skills. ${ }^{36}$

R1, the head of SMA Negeri 17 Makassar, also acknowledged that the implementation of standardized educational processes, especially in Islamic religious education subjects, has succeeded in increasing the success of Islamic religious education in schools. This can be seen in the character of students who are getting better such as obedience to religious teachings, discipline, the concern and cooperation and responsibility of students is increasing as well as the skills of students both in the abstract and concrete realms. ${ }^{37}$

R5, vice principal in the field of curriculum, assessed three things that greatly influence the improvement of students' abilities: the application of a scientific approach in learning, the use of learning models, and authentic assessment. The scientific approach and authentic learning and assessment models make the character of students better, the courage to express opinions or ideas increases, and their learning motivation increases. ${ }^{38}$

Meanwhile, according to R6, the vice principal for student affairs, the most prominent influence from implementing process standards and applying the scientific approach in SMA Negeri 17 is the attitude and skill aspect. According to him, success in the attitude aspect can be seen in the increasing number of Friday prayers and congregational prayers of students in schools. ${ }^{39}$

\footnotetext{
${ }^{36}$ R2, Guru Pendidikan Agama Islam SMA Negeri 17 Makassar, interviewed by author at SMA Negeri 17 Makassar, 7 Juli 2020 Juli 2020

${ }^{37} \mathrm{R} 1$, Kepala SMA Negeri 17 Makassar, interviewed by author at SMA Negeri 17 Makassar, 13

${ }^{38} \mathrm{R} 5$, Wakil kepala sekolah bidang kurikulum SMAN 17 Makassar, interviewed by author at SMA Negeri 17 Makassar, 13 Juli 2020

${ }^{39}$ R6, Wakil kepala sekolah bidang kesiswaan SMAN 17 Makassar, interviewed by author at SMA Negeri 17 Makassar, 13 Juli 2020
} 
Based on the description above, it can be concluded that the implementation of the standard educational process in the subjects of Islamic religious education and characters at SMA Negeri 17 Makassar can increase the success of Islamic religious education and character in the school by integrating three domains of student competence, namely the competence of attitudes, knowledge and skills. The integration of the three domains of student competence is achieved through the application of a scientific approach and the consistent application of various relevant learning models and authentic assessments.

The success of the implementation of educational process standards in supporting the success of Islamic religious education at SMA Negeri 17 Makassar, which is one of the findings in this study, supports several concepts or theories in the standard of the educational process, including:

First, applying a scientific approach in the learning process has a direct impact and an accompanying impact. The direct impact is related to the development of students' knowledge, thinking skills, and skills through observing, asking questions, gathering information, processing information, and conveying information. The impact of accompaniment relates to the development of attitude or character values that students must possess. The value of the attitude in question is an attitude of discipline, responsibility, cooperation, caring, mutual respect and others.

Thus, applying the scientific approach in learning touches three domains, namely attitudes, knowledge and skills. Learning outcomes give productive, creative, and innovative students by strengthening integrated attitudes, knowledge, and skills. The scientific approach is a golden footbridge for developing students' attitudes, knowledge, and skills, which will event ually materialize students who have good character, adequate knowledge, and skills.

Second; Application of learning models that are relevant to the scientific approach and standards-based educational processes, such as inquiry learning models, discovery learning models, problem-based learning models, project-based learning models, product-based learning models, cooperative learning models, contextual learning models and others. Those provide the broadest possible opport unity for students to participate actively in the learning process in the form of observing, trying, reasoning, presenting, and creating or creating. Provide space for students to discover and develop their own knowledge to help them develop the ability to think systematically, logically, and critically character building for students in the form of an attitude of responsibility, discipline, cooperation, caring, tolerance and mutual respect for one another.

Third; The consistent application of authentic assessment that provides space for students to demonstrate the knowledge, skills, and attitudes they already have, encourages students to get used to applying the attitudes, knowledge and skills they have in everyday life. In addition, the authentic assessment also encourages students to learn better because they are not considered complete in mastering the subject matter if they are not able to achieve and integrate the three domains of competence, namely knowledge competence, skill competence and attitude.

The results of this study also strengthen the views in cognitive-holistic learning theory (Leibnitz). This learning theory later gave birth to various learning theories, including Gestal learning theory (Kofka), field learning theory (Lewin), humanistic learning theory (Maslow and Rogers), theory constructivist learning (Jean Piaget) and others. The cognitive-holistic learning theory views learning as a mental process and a 
thought process by optimally utilizing all the potentials possessed by individuals. Learning is more than just memorizing and accumulating knowledge but how the knowledge gained is meaningful for students through the thinking process.

Cognitive-holistic learning theory highly values and accepts the exploration of students' knowledge, provides opportunities for students to discover new knowledge through the inquiry process, stimulates students to dialogue with other students and also with teachers, considers the learning process as important as learning outcomes, encourage the formation of cooperative learning, and encourage students to build their own understanding of learning outcomes, not because of the results taught by the teacher.

The findings in this study have similarities and differences with the results of previous studies. Similarities with the research results conducted by Lantif, Humairah Ulfa, and Muhammad Allejar both reveal that teachers have implemented standard educational processes well and made the learning process run effectively and efficiently. The difference is that this study's findings prove that the implementation of standardized educational processes in the subjects of Islamic religious education and characters can increase the success of Islamic religious education in schools. It can also integrate the achievement of three competency domains that must be mastered by students, namely the competence of attitudes, knowledge and skills so that these findings are a solution to the problem of Islamic religious education,, which has been complained about by many people, namely that Islamic religious education only teaches theoretical religious teachings without being accompanied by improvements in students' attitudes and skills.

\section{CLOSING}

A. The standard educational process in Islamic religious education and characters at SMA Negeri 17 Makassar begins with the preparation of a learning plan. It refers to the standard of the education process in terms of types, procedures, principles, and in terms of the components that must be included in the lesson plan. After preparing the plan, the teacher carries out the learning process using a scientific approach and learning models relevant to the educational process's standard. Furthermore, the teacher assesses the learning process both during and after the learning process takes place using authentic assessments and other forms of assessment that are in accordance with the domains of attitudes, knowledge and skills.

B. The implementation of standard educational processes in Islamic religious education and character education subjects at SMA Negeri 17 Makassar is supported by several factors: the availability of teaching staff who have educational backgrounds and qualifications according to existing regulations. Availability of sufficient textbooks. The number of students in one class is not too much. In addition to the supporting factors above, it was also found that there were inhibiting factors, namely the unavailability of adequate learning media that could support the implementation of the learning process. The quality of the implementation of supervision carried out by school principals, and education unit supervisors are still low. And there are still some students who are not able to read the Qur'an fluently. 


\section{REFERENCES}

Abdullah, Amin. Problem Epistemologis-Metodologis Pendidikan Islam, dalam Abd. Munir Mulkhan, et-al, Religisitas Iptek (Yogyakarta: Pustaka Pelajar, 1998), h. 49-65

Bafadal, Ibrahim. Seri Manajemen Peningkatan Mutu Pendidikan Berbasis Sekolah, Manajemen Perlengkapan Sekolah Teori dan Aplikasi. Jakarta: PT. Bumi Aksara, 2003.

Departemen Pendidikan Nasional. Kurikulum Pendidikan Agama Islam SMA/MA Tahun 2006(Jakarta: Depdikbud RI, 2006).

E. Mulyasa. Manajemen Berbasis Sekolah. Bandung: PT. Remaja Rosdakarya, 2004.

Fikri, Mumtazul. Konsep Pendidikan Islam Pendekatan Metode Pengajaran", Islam Futura XI, no.1 (2011): h. 117

Khuzaimah. Paradigma Pengembangan Kurikulum Penddidikan Agama Islam di Sekolah", Jurnal Kependidikan, V, no. 1 (2017): h. 82

Muhaimin. Paradigma Pendidikan Islam; Upaya Mengefektifkan Pendidikan Agama Islam di Sekolah, (Bandung: Remaja Rosdakarya, 2001) h. 89-90

Nata, Abuddin. Perspektif Islam Tentang Strategi Pembelajaran. Cet. II; Kencana, 2011.

Peraturan Menteri Pendidikan dan Kebudayaan Nomor 143 Tahun 2014 tentang Petunjuk Teknis Pelaksanaan Jabatan Fungsional Pengawas Sekolah dan Angka Kreditnya.

Republik Indonesia. Undang-undang R.I. Nomor 20 Tahun 2003 Tentang Sistem Pendidikan Nasional, bab I, pasal 3.

Rusman. Model-model Pembelajaran, Mengembangkan Profesionalisme Guru.

Sanjaya, Wina. Strategi Pembelajaran Berorientasi Standar Proses Pendidikan. Jakarta: Kencana, 2009.

Shihab, M. Quraish. Tafsir Al-Mishbah. Jakarta; Lentera Hati, 2002.

SK Menpan No. 091/KEP/MEN.PAN/10/2001 tentang Jabatan Fungsional Pengawas Sekolah dan Angka Kreditnya

Usman, Uzer. Menjadi Guru Profesional. Bandung: Remaja Rosdakarya. 